\title{
Effect of Methods and Time of Sowing on Growth Indices in Rice Fallow Blackgram (Phaseolus mungo L.) Under Machine Transplanted Rice System
}

\author{
K. Maruthupandi ${ }^{*}$ and A. Veeramani
}

Department of Agronomy, Agricultural College and Research Institute, Madurai-625 104, Tamil Nadu, India

*Corresponding author

\author{
A B S T R A C T
}

The Field experiments was conducted at Agricultural College and Research Institute, Madurai during kharif 2012 and rabi seasons 2012-2013 to study the effects of methods and time of

\section{Keywords}

Blackgram, Rice, Machine transplanted rice system.

Article Info

Accepted:

20 September 2017

Available Online:

10 November 2017 sowing on soil moisture per cent in rice fallow blackgram. The treatments such as in main plot, three method of sowing line dibbling $\left(\mathrm{M}_{1}\right)$, random dibbling $\left(\mathrm{M}_{2}\right)$, broadcasting $\left(\mathrm{M}_{3}\right)$ and sub plot, time of sowing $10\left(\mathrm{~T}_{1}\right), 7\left(\mathrm{~T}_{2}\right), 4\left(\mathrm{~T}_{3}\right)$ and $1\left(\mathrm{~T}_{4}\right)$ days before rice harvest. The soil moisture percentage was significantly influenced by methods and time of sowing. The results were observed Line dibbling recorded more in case of growth indices like CGR, RGR and NAR. Random dibbling was the next best method of sowing for getting the increased plant growth indices of rice fallow blackgram during kharif and rabi respectively when line dibbling combined with the time of sowing of 10 days before rice harvest $\left(\mathrm{M}_{1} \mathrm{~T}_{1}\right)$. The sowing method of line dibbling coupled with 10 days before rice harvest $\left(\mathrm{M}_{1} \mathrm{~T}_{1}\right)$ realized higher seed yield of $685 \mathrm{~kg} \mathrm{ha}^{-1}$ during kharif and random dibbling method of sowing coupled with 10 days before rice harvest $\left(\mathrm{M}_{2} \mathrm{~T}_{1}\right)$ recorded seed yield of $622 \mathrm{~kg}$ $\mathrm{ha}^{-1}$ during rabi season.

\section{Introduction}

In India pulses cultivated in an area of 20.05 million hectare with production of 11.14 million tones with productivity of $556 \mathrm{~kg}$ per hectare. In Tamil Nadu, Black gram occupies an area of 2.76 lakhs hectares with a production of 1.33 lakh tonnes which access for average productivity of $488 \mathrm{~kg}$ per hectare (Anonymous, 2004).Except barring seed material, farmers followed almost zero input under rice fallow pulses cultivation. Hence, the productivity in rice fallow pulse is always far below the normal. Even what is followed for rainfed crops is not adopted for these energy intensive crops. Hence it is highly imperative to develop management techniques to realize the yield potential of pulse under rice fallow condition. Even though, sufficient moisture is made available to the sown crop by following the appropriate time of sowing, placement of seeds on the surface of soil in broadcasting is likely to cause poor contact between soil and seeds that may cause poor germination which need to be taken care of by following the proper method of sowing. No doubt that dibbling method of sowing is the best method of sowing for almost all the crops except small seeded crops (Subramanian, 1978). Here the growth indices are show the continue the growth and we can determine the yield. As dibbling helps the 
seeds to absorb required moisture and nutrients due to better contact between soil and seeds at optimum depth of sowing for e.g. 2-3 cm depth, the crop could able to survive better maintaining optimum crop stand (Palaniappan et al., 1978). It is obvious that dibbling is possible in fallow lands and in wide spaced crops (IRRI 1981).Early sowing (24 December) registered significantly more number of branches/plant (14.7) which is at par with 7 January sowing (13.0). However delayed sowing (22 January) recorded significantly lower number of branches/plant (Ravisankar et al., 2010).

Chickpea sown on December 1 produced maximum number of pods/plant. Lowest value obtained December 20 sowing. This could be attributed to higher growth attributes, which may responsible for better source and sink relation (Kabir et al., 2009). The growth indices to stage wise we can follow suitable management for better yield.

\section{Materials and Methods}

The research was conducted at the Agricultural College and Research Institute, Madurai, India $9^{\circ} 54^{\prime} \mathrm{N}$ latitude and $78^{\circ} 54^{\prime} \mathrm{E}$ longitude at an elevation of $147 \mathrm{~m}$ above Mean Sea Level. The farm is located in the Southern Agro climatic Zone of the Tamil Nadu. The experimental farm is characterized by tropical climate with mean annual rainfall of $617.4 \mathrm{~mm}$ distributed over 34 rainy days. The mean maximum and minimum temperatures were $35.0^{\circ} \mathrm{C}$ and $24.5^{\circ} \mathrm{C}$, respectively. The mean daily pan evaporation and relative humidity recorded during the crop season were $4.04 \mathrm{~mm}$ and 79.9 per cent, respectively. The weather parameters prevailed during the cropping period (July 2012 to March 2013). The type of soil was clay loam, which contained organic carbon (0.44, 0.51\%), N 230,262 kg/ha, P 24,19.78 $\mathrm{kg} / \mathrm{ha}, \mathrm{K} 270,230 \mathrm{~kg} / \mathrm{ha},{ }_{\mathrm{pH}}$ 6.37,7.52,EC $0.12,0.32$ kharif and rabi respectively.

Treatments were implemented during the machine transplanted rice harvest stage, rice was hand harvested and their residues were allowed as a part of the continuous rice fallow blackgram rotation experiment. The growth stage from July 2012 to March 2013.The experiment was laid out in split plot design with three replications. The layout plan adopted for the experiment is Main plotMethods of sowing $\mathrm{M}_{1}$ - Line dibbling, $\mathbf{M}_{2}$ Random dibbling, $\mathrm{M}_{3}$ - Broadcasting and Sub plot -Time of sowing $\mathrm{T}_{1}$ - 10 days before rice harvest, $\mathrm{T}_{2}-7$ days before rice harvest, $\mathrm{T}_{3}-4$ days before rice harvest, $\mathrm{T}_{4}-1$ day before rice harvest. Soil moisture at $0-15 \mathrm{~cm}$ depth was estimated gravimetrically at 15 days interval from each time of sowing. Five plants per plot were sampled was recorded at 20,40 and $60^{\text {th }}$ day from each time of sowing by measuring the crop growth rate, relative growth rate, net assimilation rate and yield observation of the plant mean value were recorded. The experimental data were statistically analyzed by following procedure described by Panse and Sukhmate (1985). The data pertaining the critical difference were worked out at 5 percent probability level $\mathrm{p}=0.05$ and nonsignificant values were denoted as NS.

\section{Results and Discussion}

\section{Crop growth rate}

The sowing method of line dibbling $\left(\mathrm{M}_{1}\right)$ exhibited its superiority to increase CGR by 5.18 and $4.25 \mathrm{gm}^{-2}$ day $^{-1}$ between 20-40 DAS and 4.33 and $4.14 \mathrm{gm}^{-2}$ day $^{-1}$ between 40-60 DAS during kharif and rabi respectively (Table 1). It was followed by random dibbling $\left(\mathrm{M}_{2}\right)$. Among various time of sowing tried, 10 days before rice harvest $\left(\mathrm{T}_{1}\right)$ registered higher CGR of 5.51 and $4.85 \mathrm{~g} \mathrm{~m}^{-2}$ day $^{-1}$ between 20 40 and 40-60 DAS respectively during kharif 
and 4.16and $4.03 \mathrm{~g} \mathrm{~m}^{-2}$ day $^{-1}$ between $20-40$ and 40-60 DAS respectively during rabi (Fig. 1). The interaction effect between the treatments on CGR was not noticed SImilar finding of the higher growth rate recorded from the uniform population (Biswas et al., 2002). Lower growth rate was recorded in broadcasting method of sowing and under time of sowing of 1 day before rice harvest.

\section{Relative growth rate}

RGR was numerically increased by methods and time of sowing (Table 1). Line dibbling $\left(\mathrm{M}_{1}\right)$ of blackgram seeds numerically increased the RGR values to 0.022 and 0.036 $\mathrm{g} \mathrm{g}^{-1}$ day $^{-1}$ during kharif and rabi respectively between 20-40 DAS and 0.040 and $0.050 \mathrm{~g}$ $\mathrm{g}^{-1}$ day $^{-1}$ during kharif and rabi respectively between 40-60 DAS. It was followed by random dibbling $\left(\mathrm{M}_{2}\right)$. Adoption of sowing 10 days before rice harvest $\left(T_{1}\right)$ recorded numerically higher RGR values of 0.022 and $0.036 \mathrm{~g} \mathrm{~g} \mathrm{~g}^{-1}$ day $^{-1}$ between 20-40 DAS and 0.046 and $0.048 \mathrm{~g} \mathrm{~g}^{-1}$ day $^{-1}$ between 40-60 DAS during kharif and rabi respectively (Fig. 1). This was closely followed by 7 days before rice harvest $\left(T_{2}\right)$. Interaction effect was not noticed between methods and time of sowing in respect of RGR during both the seasons.

\section{Net Assimilation rate}

Net assimilation rate (NAR) of rice fallow blackgram was influenced numerically in methods and time of sowing (Table 1). Decreasing trend in NAR was noticed with increasing in age of the crop in both the season. Among the methods of sowing numerically more net assimilation rate was recorded in line dibbling $\left(\mathrm{M}_{1}\right)$ which were 0.238 and $0.218 \mathrm{mg} \mathrm{cm}^{-2}$ day $^{-1}$ between $20-40$ DAS and 0.137 and $0.120 \mathrm{mg} \mathrm{cm}^{-2}$ day ${ }^{1}$ between 40-60 DAS during kharif and rabi respectively. Random dibbling $\left(\mathbf{M}_{2}\right)$ has occupied $2^{\text {nd }}$ in registering the net assimilation rate during both the seasons. In the case of time of sowing, 10 days before rice harvest (T1) has numerically recorded higher net assimilation rate $(0.241$ and 0.210 $\mathrm{mg} \mathrm{cm}^{-2}$ day $^{-1}$ between 20-40 DAS and 0.153 and $0.120 \mathrm{mg} \mathrm{cm}^{-2}$ day $^{-1}$ between 40-60 DAS during kharif and rabi respectively (Fig. 1).

This was closely followed by the treatment 7 days before rice harvest $\left(\mathrm{T}_{2}\right)$ during both the seasons regardless of stages. The interaction between the methods and time of sowing on net assimilation rate was not significant.

\section{Grain yield}

Significant difference between the methods and time of sowing on seed yield of blackgram was observed during both the seasons. The data on seed yield was present in Table 1. The seed yield of blackgram was increased markedly with line dibbling $\left(\mathrm{M}_{1}\right)$ which recorded the seed yield of $525 \mathrm{~kg} \mathrm{ha}^{-1}$ during kharif and $512 \mathrm{~kg} \mathrm{ha}^{-1}$ during rabi followed by random dibbling $\left(\mathrm{M}_{2}\right)$ (389 and $346 \mathrm{~kg} \mathrm{ha}^{-1}$ during kharif and rabi respectively). Broadcasting $\left(\mathrm{M}_{3}\right)$ recorded lower seed yield of $243 \mathrm{~kg} \mathrm{ha}^{-1}$ and $238 \mathrm{~kg}$ $\mathrm{ha}^{-1}$ during kharif and rabi respectively. Regarding time of sowing, 10 days before rice harvest $\left(\mathrm{T}_{1}\right)$ recorded with higher seed yield (459 kg ha ${ }^{-1}$ during kharif and $429 \mathrm{~kg} \mathrm{ha}^{-1}$ during rabi). However, it was on par with 7 days before rice harvest $\left(\mathrm{T}_{2}\right)$ during rabi.

The seed yield was significantly low under 1 day before rice harvest $\left(\mathrm{T}_{4}\right)\left(306 \mathrm{~kg} \mathrm{ha}^{-1}\right.$ and $292 \mathrm{~kg} \mathrm{ha}^{-1}$ during rabi and kharif respectively). Interaction effect of methods and time of sowing on seed yield was found significant during both the seasons. Sowing method of line dibbling coupled with 10 days before rice harvest $\left(\mathrm{M}_{1} \mathrm{~T}_{1}\right)$ realized higher seed yield of $685 \mathrm{~kg} \mathrm{ha}^{-1}$ during kharif and 622 $\mathrm{kg} \mathrm{ha}^{-1}$ during rabi (Fig. 2). 
Table.1 Effect of method and time of sowing of growth indices on blackgram in machine transplanted rice system

\begin{tabular}{|c|c|c|c|c|c|c|c|c|c|c|c|c|c|c|}
\hline \multirow{3}{*}{ Treatment } & \multicolumn{4}{|c|}{$\begin{array}{l}\text { Crop growth rate } \\
\quad\left(\mathrm{g} \mathrm{m}^{-2} \mathrm{day}^{-1}\right)\end{array}$} & \multicolumn{4}{|c|}{$\begin{array}{c}\text { Relative growth rate } \\
\left(\mathrm{g} \mathrm{g} \mathrm{g}^{-1} \text { day }^{-1}\right)\end{array}$} & \multicolumn{4}{|c|}{$\begin{array}{l}\text { Net assimilation rate } \\
\left(\mathrm{mg} \mathrm{cm}^{-2} \text { day }^{-1}\right)\end{array}$} & \multirow{3}{*}{$\begin{array}{c}\begin{array}{c}\text { Yield } \\
\text { (kg/ha) }\end{array} \\
\begin{array}{c}\text { Kharif, } \\
2012\end{array} \\
\begin{array}{c}\text { Post } \\
\text { Harvest }\end{array}\end{array}$} & \multirow{3}{*}{$\begin{array}{c}\begin{array}{c}\text { Yield } \\
\text { (kg/ha) }\end{array} \\
\begin{array}{c}\text { Rabi, } \\
\text { 2012-2013 }\end{array} \\
\begin{array}{c}\text { Post } \\
\text { Harvest }\end{array}\end{array}$} \\
\hline & \multicolumn{2}{|c|}{ Kharif, 2012} & \multicolumn{2}{|c|}{$\begin{array}{l}\text { Rabi, 2012- } \\
2013\end{array}$} & \multicolumn{2}{|c|}{ Kharif, 2012} & \multicolumn{2}{|c|}{ Rabi, 2012-2013 } & \multicolumn{2}{|c|}{ Kharif, 2012} & \multicolumn{2}{|c|}{$\begin{array}{c}\text { Rabi, 2012- } \\
2013\end{array}$} & & \\
\hline & $\begin{array}{c}20- \\
40 \\
\text { DAS } \\
\end{array}$ & $\begin{array}{c}40- \\
60 \\
\text { DAS } \\
\end{array}$ & $\begin{array}{c}20- \\
40 \\
\text { DAS }\end{array}$ & \begin{tabular}{|c|}
$40-60$ \\
DAS
\end{tabular} & $\begin{array}{c}20-40 \\
\text { DAS }\end{array}$ & $\begin{array}{c}40-60 \\
\text { DAS }\end{array}$ & $\begin{array}{l}20-40 \\
\text { DAS }\end{array}$ & $\begin{array}{l}\text { 40-60 } \\
\text { DAS }\end{array}$ & $\begin{array}{c}20- \\
40 \\
\text { DAS } \\
\end{array}$ & $\begin{array}{c}40- \\
60 \\
\text { DAS } \\
\end{array}$ & $\begin{array}{l}20-40 \\
\text { DAS }\end{array}$ & $\begin{array}{c}40- \\
60 \\
\text { DAS } \\
\end{array}$ & & \\
\hline \multicolumn{15}{|l|}{ Methods of sowing } \\
\hline$M_{1}$ - Line dibbling & 5.18 & 4.33 & 4.25 & 4.14 & 0.022 & 0.040 & 0.036 & 0.050 & 0.238 & 0.137 & 0.218 & 0.120 & 525 & 512 \\
\hline $\mathrm{M}_{2}$ - Random dibbling & 4.65 & 3.90 & 3.35 & 3.25 & 0.020 & 0.035 & 0.028 & 0.046 & 0.231 & 0.134 & 0.214 & 0.110 & 389 & 346 \\
\hline$M_{3}$ - Broadcasting & 4.15 & 3.24 & 2.63 & 2.5 & 0.010 & 0.026 & 0.020 & 0.043 & 0.226 & 0.131 & 0.140 & 0.100 & 243 & 238 \\
\hline SEd & 0.22 & 0.126 & 0.19 & 0.17 & 0.001 & 0.001 & 0.002 & 0.003 & 0.010 & 0.003 & 0.002 & 0.001 & 14.7 & 14.13 \\
\hline $\mathrm{CD}(\mathrm{P}=0.05)$ & 0.44 & 0.350 & 0.36 & 0.34 & NS & NS & NS & NS & NS & NS & NS & NS & 28.37 & 28.14 \\
\hline \multicolumn{15}{|l|}{ Time of sowing } \\
\hline$T_{1-} 10$ days before rice harvest & 5.51 & 4.85 & 4.16 & 4.03 & 0.022 & 0.046 & 0.036 & 0.048 & 0.241 & 0.153 & 0.210 & 0.120 & 459 & 429 \\
\hline$T_{2}-07$ days before rice harvest & 5.07 & 3.53 & 3.43 & 3.55 & 0.020 & 0.040 & 0.030 & 0.047 & 0.213 & 0.131 & 0.190 & 0.110 & 411 & 408 \\
\hline$T_{3^{-}} 04$ days before rice harvest & 4.41 & 3.50 & 3.41 & 3.3 & 0.020 & 0.033 & 0.030 & 0.047 & 0.197 & 0.128 & 0.190 & 0.110 & 366 & 331 \\
\hline$T_{4}$ - 01 day before rice harvest & 3.64 & 3.42 & 2.64 & 2.7 & 0.011 & 0.028 & 0.020 & 0.044 & 0.177 & 0.120 & 0.130 & 0.100 & 306 & 292 \\
\hline SEd & 0.24 & 0.23 & 0.18 & 0.16 & 0.001 & 0.002 & 0.002 & 0.003 & 0.002 & 0.004 & 0.004 & 0.003 & 12.63 & 11.83 \\
\hline $\mathrm{CD}(\mathrm{P}=0.05)$ & 0.51 & 0.43 & 0.35 & 0.33 & NS & NS & NS & NS & NS & NS & NS & NS & 24.77 & 23.18 \\
\hline
\end{tabular}


Fig. 1. Effect of methods and time of sowing on CGR, RGR and NAR in rice fallow blackgram
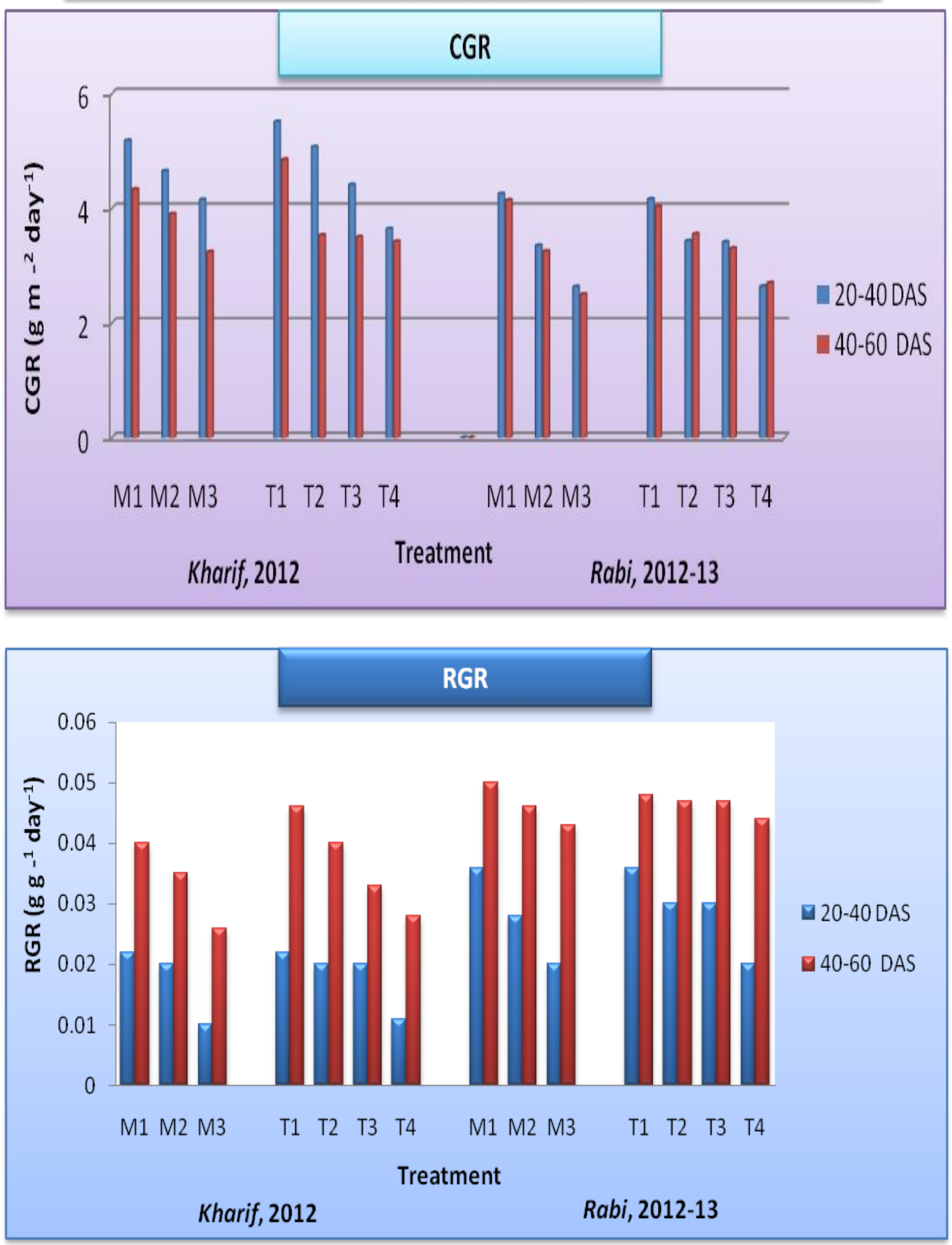


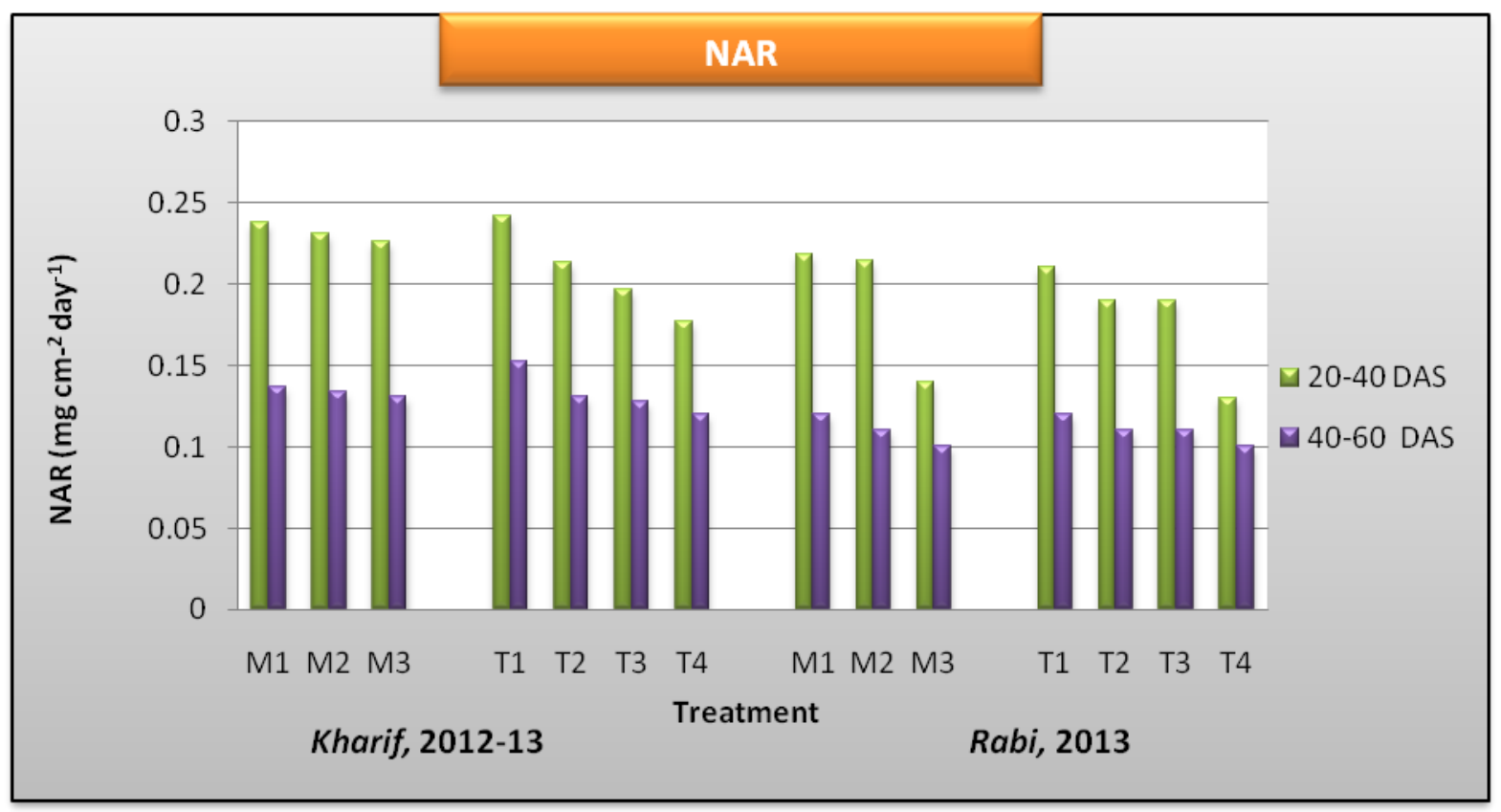

Fig.2 Effect of methods and time of sowing on seed yield $\left(\mathrm{kg} \mathrm{ha}^{-1}\right)$ in rice fallow blackgram

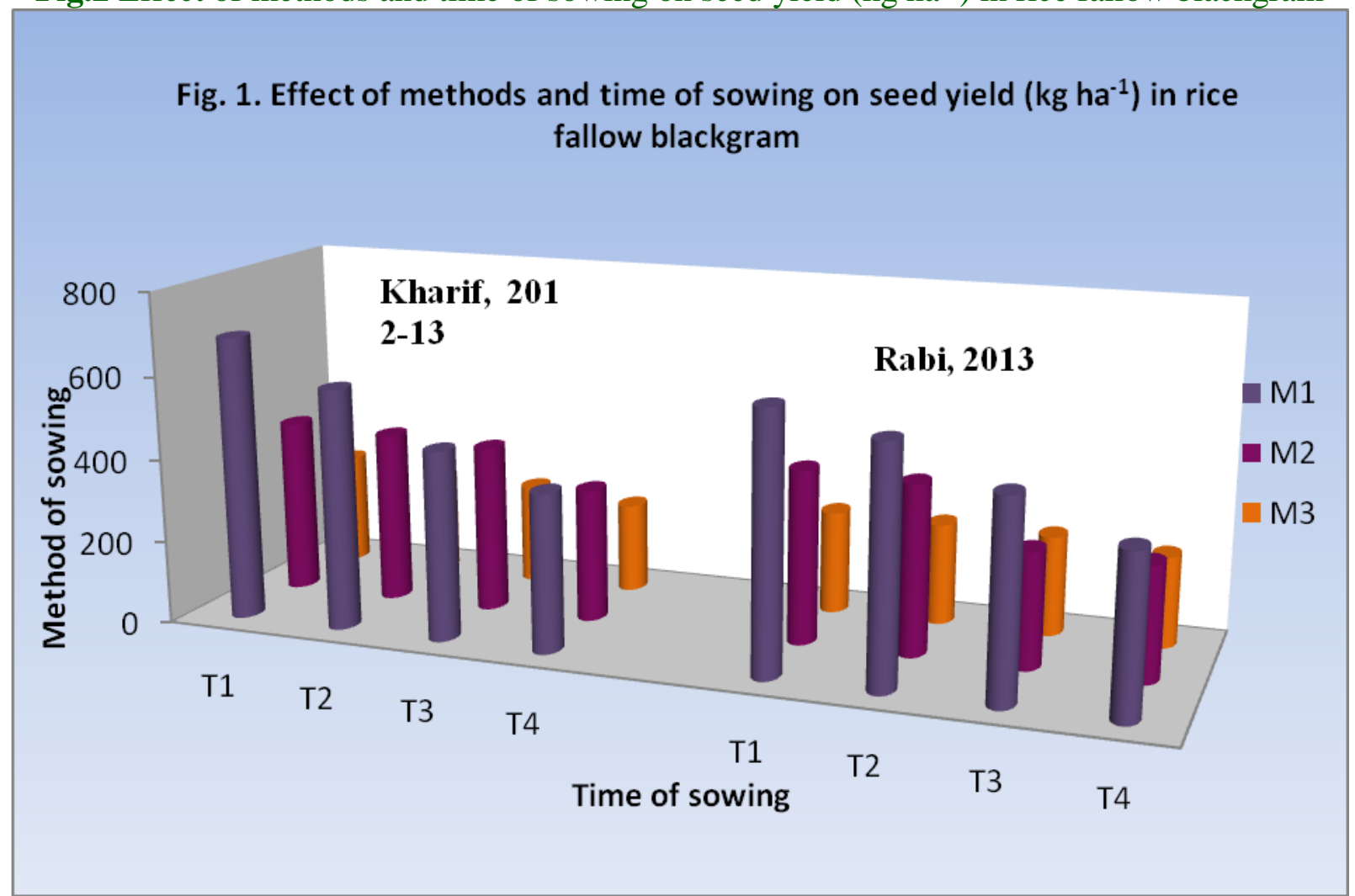

It was followed by line dibbling with 7 days before rice harvest $\left(\mathrm{M}_{1} \mathrm{~T}_{2}\right)$ which recorded the seed yield to the tune of $581 \mathrm{~kg} \mathrm{ha}^{-1}$ and 568 $\mathrm{kg} \mathrm{ha}^{-1}$ during kharif and rabi respectively.
The minimum seed yield of $217 \mathrm{~kg} \mathrm{ha}^{-1}$ during kharif and $219 \mathrm{~kg} \mathrm{ha}^{-1}$ during rabi was recorded in the treatment combination of broadcasting with 1 day before rice harvest 
$\left(\mathrm{M}_{3} \mathrm{~T}_{4}\right)$. The per cent increase in seed yield was 53.7 and 53.5 over broadcasting during kharif and rabi respectively. Similar yield increase by the dibbling method of sowing was reported by Kumar et al., (1992) who reported that dibbling the seeds immediately after harvest of rice recorded higher seed yield than broadcasting of seeds in standing crop of rice.

From the investigation, it could be concluded that line dibbling was found to be the best method under method of sowing and 10 days before rice harvest is the best time of sowing under time of sowing for achieve higher growth indices and better crop establishment in rice fallow blackgram. The combination of line dibbling and sowing seeds 10 days before rice harvest is considered as best cultivation mode for getting higher CGR similar level of RGR, NAR and higher yield of rice fallow blackgram during kharif and rabi season in southern India.

\section{References}

Anonymous. 2004. Agricultural statistics at a glance. Mo. and Go.pp. 58.

Biswas, D.K., Haque, M.M., Hamid, A. and Ahmed Temporal, J.U. 2002. Effects on Gas Exchange Characteristics of Blackgram. Pakistan J. Biological Sci.,
5 (2): 173-176.

IRRI, 1981. Annual report for 1981. International Rice Research Institute, Manila, Philippines, pp. 496-497.

Kabir, F.A.H.M., Bari, M.N., Karim, M.A., Khaliq, Q.A. and Ahmed, J.U. 2009. Effect of sowing and cultivars on the growth and yield of chickpea under rainfed condition. Bangladesh. J. Agric Res., 50 (6): 1017-1025.

Palaniappan, S.P., Thirunavukarasu, D.R. and Subbiah, E. 1978. Length and width method for estimating leaf area of blackgram (unpublished).

Panse, V.G. and Sukhatme, P.V. 1985. Statistical methods for agricultural workers. Pub.ICAR. New Delhi, pp. 187-197.

Ravisankar, N., Balakrishnan, M., Ghoshal Chaudhari, S., Ambast, S.K., Srivastava, R.C., Subramani, T. and Bommayasamay, N. 2010. Evaluation of time, method of sowing and varieties for table-purpose groundnut (Arachis hypogaea) under Island ecosystem. Indian J. Agric. Sci., 80 (4): 293-297.

Subramanain, M. 1978. Studies on the response of blackgram (Vigna mungo. L. Hepper.) to phosphorus in different systems of cultivation. Ph.D Thesis, AC \& RI, TNAU, Coimbatore.

\section{How to cite this article:}

Maruthupandi, K. and Veeramani, A. 2017. Effect of Methods and Time of Sowing on Growth Indices in Rice Fallow Blackgram (Phaseolus mungo L.) Under Machine Transplanted Rice System. Int.J.Curr.Microbiol.App.Sci. 6(11): 2738-2744.

doi: https://doi.org/10.20546/ijcmas.2017.611.323 